\title{
Iatrogenic Growth Failure
}

National Cancer Institute

\section{Source}

National Cancer Institute. Iatrogenic Growth Failure. NCI Thesaurus. Code C118683.

Growth failure due to medical intervention. 